\title{
RECOVERY OF CERIUM \\ AND LANTHANUM BY OZONATION OF LANTHANIDE SOLUTIONS
}

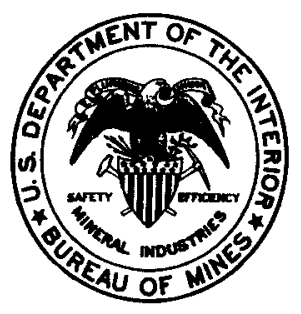

UNITED STATES DEPARTMENT OF THE INTERIOR BUREAU OF MINES 


\section{DISCLAIMER}

This report was prepared as an account of work sponsored by an agency of the United States Government. Neither the United States Government nor any agency Thereof, nor any of their employees, makes any warranty, express or implied, or assumes any legal liability or responsibility for the accuracy, completeness, or usefulness of any information, apparatus, product, or process disclosed, or represents that its use would not infringe privately owned rights. Reference herein to any specific commercial product, process, or service by trade name, trademark, manufacturer, or otherwise does not necessarily constitute or imply its endorsement, recommendation, or favoring by the United States Government or any agency thereof. The views and opinions of authors expressed herein do not necessarily state or reflect those of the United States Government or any agency thereof. 


\section{DISCLAIMER}

Portions of this document may be illegible in electronic image products. Images are produced from the best available original document. 


\title{
RECOVERY OF CERIUM AND LANTHANUM BY OZONATION OF LANTHANIDE SOLUTIONS
}

\author{
By D. J. Bauer and R. E. Lindstrom \\ By D. J. Bauer and R. E. Lindstrom
}

* * * * * * * * * * report of investigations 7123

\section{UNITED STATES DEPARTMENT OF THE INTERIOR}

\author{
BUREAU OF MINES
}


This publication has been cataloged as follows:

\section{Bauer, Donald J}

Recovery of cerium and lanthanum by ozonation of lanthanide solutions, by D. J. Bauer and R. E. Lindstrom. [Washington] U.S. Dept. of the Interior, Bureau of Mines [1968]

9 p. illus., tables. (U. S. Bureau of Mines. Report of investigations 7123)

Includes bibliography.

1. Cerium. 2. Lanthanum. I. Lindstrom, Roald E., jt. auth. II. Title. (Series)

TN23.U7 no. $7123 \quad 622.06173$

U. S. Dept. of the Int. Library 
CONTENTS

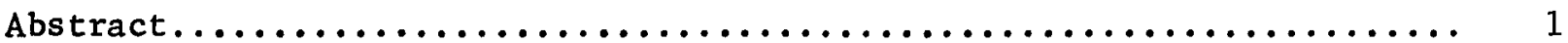

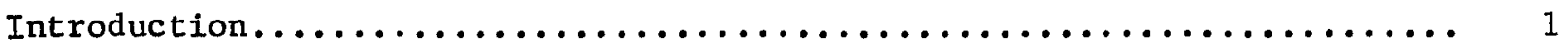

Materials, apparatus, and procedure......................... 2

Discussion and results................................. 3

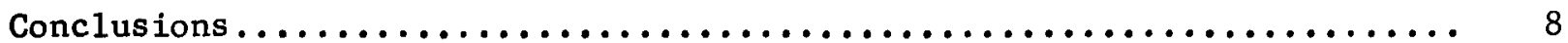

References............................................ 9

\section{ILLUSTRATIONS}

Fig.

1. Effect of reaction time on $\mathrm{CeO}_{2}$ recovery from lanthanide chloride solution at ambient temperature..................... 4

2. Effect of reaction time on $\mathrm{CeO}_{2}$ recovery from lanthanide chloride

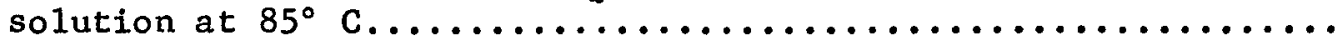

\section{TABLES}

1. X-ray fluorescent analysis of rare-earth-oxide feed materia1...... 3

2. Recovery and purity of $\mathrm{CeO}_{2}$ and $\mathrm{La}_{2} \mathrm{O}_{3}$ as a function of $\mathrm{pH}$ and

time, at ambient temperature........................ 6

3. Recovery and purity of $\mathrm{CeO}_{2}$ and $\mathrm{La}_{2} \mathrm{O}_{3}$ as a function of $\mathrm{pH}$ and

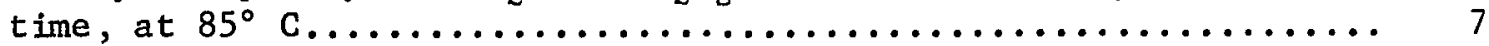

4. Two-step recovery of $\mathrm{CeO}_{2}$ and $\mathrm{La}_{2} \mathrm{O}_{3} \ldots \ldots \ldots \ldots \ldots \ldots \ldots \ldots \ldots \ldots$ 


\title{
RECOVERY OF CERIUM AND LANTHANUM BY OZONATION OF LANTHANIDE SOLUTIONS
}

by

D. J. Bauer ${ }^{1}$ and R. E. Lindstrom ${ }^{2}$

\begin{abstract}
Oxidation of mixed lanthanide solutions with ozone at $\mathrm{pH} 4.5$ and at ambient temperature resulted in precipitation of 98 percent of the origina1 cerium present. Corresponding cerium purity was increased from 50 to 98 percent. A second ozone oxidation-precipitation step produced cerium of 99.9 percent purity in high yield from the 98 -percent-pure material.

Alternately, ozonation at $\mathrm{pH} 6.5$ and $85^{\circ} \mathrm{C}$ differentially precipitated cerium and rare-earth elements heavier than cerium and left 89 percent of the original lanthanum in solution at a purity of 95 percent. Subsequent recovery of cerium from the heavier rare-earth elements in the precipitate was accomplished by dissolving the precipitate in dilute mineral acid and reoxidizing the cerium with ozone at $\mathrm{pH} 4.5$ and at ambient temperature. The filtrate contained an enriched praseodymium-neodymium-samarium-europium mixture that is amenable to separation by ion exchange or solvent extraction.
\end{abstract}

\section{INTRODUCTION}

Cerium and lanthanum are among the most abundant of the rare-earth elements, and their recovery and purification have considerable economic importance. Cerium compounds find their main use as glass-polishing agents; they also are of value as glass-coloring agents and as opacifiers in glazes and ename1s. Lanthanum, in addition to being used in glass, is being used in increasing quantities as a petroleum-cracking catalyst.

The separation of cerium and lanthanum from a wide variety of source materials has been accomplished by several methods including fractional crystallization $(\underline{4}, \underline{6}), 3$ basicity precipitation (3), ion exchange (ㅁ) , and solvent

${ }^{I}$ Chemical research engineer.

${ }^{2}$ Supervisory chemical research engineer. Both authors are with the Reno Metallurgy Research Center, Bureau of Mines, Reno, Nev.

${ }^{3}$ Underlined numbers in parentheses refer to items in the list of references at the end of this report. 
extraction $(2,7)$. Probably the best known and most widely used techniques for cerium purification are those based on the oxidation of cerium in solution to the tetravalent state. Persulfates, permanganates, and hypochlorites are frequently used for this oxidation reaction. The tetravalent cerium can be recovered from the rare-earth solution by precipitation of the comparatively insoluble cerium (IV) by $\mathrm{pH}$ control (3) or by extraction of a ceric salt into an organic extractant (7). Under some conditions a ceric salt (for example, ceric nitrate) will precipitate if the $\mathrm{pH}$ of the solution is raised to 2 or higher. A few repetitions of this process will produce a basic ceric salt more than 99-percent pure, but the effort involved in the procedure is considerable, and the yield is relatively low.

A solvent extraction process employing tri-n-butyl phosphate solvent has been used to extract ceric nitrate, probably as the hexanitrato-cerate complex. This procedure is capable of producing high-purity cerium compounds with high yields in a few countercurrent stages. In another method, cerous hydroxide is oxidized to hydrated ceric oxide by heating the solid rare-earth mixture in air. Leaching of this material under controlled pH conditions will dissolve the trivalent rare-earth hydroxides, whereas the ceric salt remains insoluble.

Lanthanum, having but one oxidation state, is considerably more difficult to purify than cerium. One traditional technique utilizes the addition of ammonia to a hot solution of rare-earth salts. Because of its greater basicity, the lanthanum remains in solution at $\mathrm{pH}$ values approaching neutrality, while the less basic heavier rare-earth elements are precipitated. This procedure will produce a lanthanum salt of $>90$-percent purity, but recovery is rarely greater than 75 percent.

A possible technique for oxidizing and purifying cerium that has received little attention is based on the well-known capabilities of ozone as an oxidant (1). Ozone, which has an oxidation potential of minus 2.07 volts in acid solution, is surpassed in electronegative oxidation potential only by fluorine among the commonly used oxidizing agents. Ozone is known to oxidize ferrous ion to ferric, chromous to chromate, sulfide to sulfate, and nitrite to nitrate. Based on the known oxidation potential of minus 1.74 for the $\mathrm{Ce}^{+3}$ (aq) $\overrightarrow{\mathrm{Ce}^{+4}}$ (aq) $+\mathrm{e}^{-}$couple, ozone would be expected to oxidize a cerous salt in solution to the ceric form.

This report is concerned with a Bureau of Mines investigation of the ozone oxidation of cerium ion in aqueous solution and the simultaneous pre cipitation of a purified cerium product. Another goal of the study was to investigate the oxidation-precipitation reaction as a means of coprecipitating rare-earth elements heavier than cerium with the cerium to provide an upgraded lanthanum fraction in the filtrate.

\section{MATERIALS, APPARATUS, AND PROCEDURE}

Charge solutions were prepared by dissolving cerium-group rare-earth oxides in sulfuric, nitric, or hydrochloric acid and, for the majority of tests, diluting to a final concentration of $12 \mathrm{~g} / 1\left(\mathrm{RE}_{2} \mathrm{O}_{3}\right.$ basis). The 
rare-earth oxides were obtained from the mineral bastnasite and had the composition 1 isted in table 1.

TABLE 1. - X-ray fluorescent analysis of rare-earth-oxide feed material

\begin{tabular}{|c|c|}
\hline Rare-earth species & Analysis, percent \\
\hline 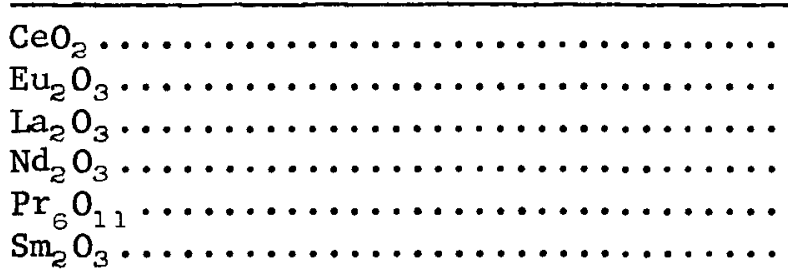 & $\begin{array}{r}50.0 \\
.1 \\
36.0 \\
9.7 \\
3.5 \\
.7\end{array}$ \\
\hline
\end{tabular}

Ozone was produced in a Welsbach-type ozonator 4 operating at 15,000 volts and $60 \mathrm{cps}$. The generator was controlled to deliver approximately 2.5 grams of ozone per hour with an oxygen flow of $0.02 \mathrm{cfm}$ at 8 psi. Breathing oxygen was used because of its low moisture content. Toxic ozone fumes were confined in a hood.

Individual experiments were conducted with $800-\mathrm{ml}$ of charge solution in 1-1iter, open-top, glass reaction vessels. Solutions were stirred and heated to $85^{\circ} \mathrm{C}$ during selected experiments. It was usually necessary to add water to the solution during the high temperature experiments to maintain a constant volume. Addition of ammonia was necessary to neutralize acid formed during the oxidation reaction. Ozone and ammonia gases were introduced into the rare-earth solution through fritted glass tubes. In any given experiment the addition of ozone was continued until essentially all of the cerium had precipitated or until a predetermined reaction time was reached. Precipitation of the cerium was complete when the $\mathrm{pH}$ of the solution remained constant without the addition of ammonia. The precipitated $\mathrm{CeO}_{2}$ was recovered by filtration.

Cerium precipitation was followed by a $\mathrm{Ce}^{144}$ tracer for the initial reaction-time studies. Rare-earth elements remaining in solution were precipitated with oxalic acid, and the rare-earth oxalates were roasted to the oxide at $1,700^{\circ} \mathrm{F}$. All rare-earth oxide products were analyzed by $\mathrm{X}$-ray fluorescence. Inasmuch as the cerium products were roasted to $\mathrm{CeO}_{2}$ before weighing, and analytical results were reported on an oxide basis, the cerium precipitates are referred to as $\mathrm{CeO}_{2}$ or ceric oxide throughout this report. However, it should be noted that the cerium probably precipitated as hydrated ceric oxide, $\mathrm{CeO}_{2} \cdot 2 \mathrm{H}_{2} \mathrm{O}$.

\section{DISCUSSION AND RESULTS}

Since cerium compounds are oxidized under certain conditions by oxygen, preliminary experiments were conducted with air or oxygen to establish a basis for comparison with results subsequently obtained with ozone. Negative results

4 Reference to specific brands is made for identification only and does not imply endorsement by the Bureau of Mines. 


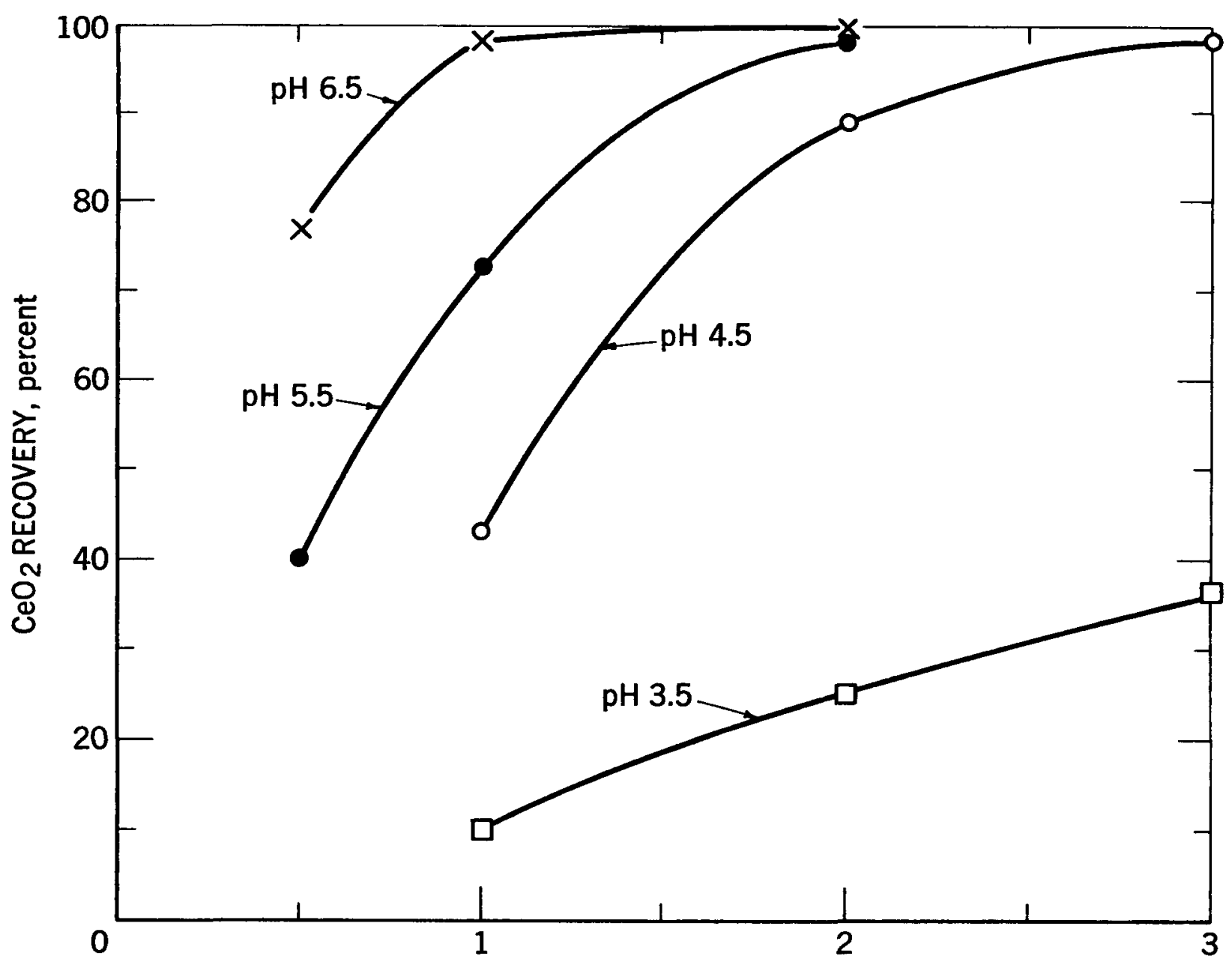

REACTION TIME, hours

FIGURE 1. - Effect of Reaction Time on $\mathrm{CeO}_{2}$ Recovery From Lanthanide Chloride Solution at Ambient Temperature.

(for example, no cerium oxidation) were obtained with $\mathrm{pH}$ values as high as 5.5 at ambient temperature. Oxidation-precipitation started when the temperature was increased to $85^{\circ} \mathrm{C}$ and the $\mathrm{pH}$ to 6.5 with either air or oxygen. Under these conditions considerable quantities of trivalent hydroxides were coprecipitated with the tetravalent cerium oxide. Although the $\mathrm{CeO}_{2}$ precipitate was badly contaminated, the rare-earth elements contained in the filtrate analyzed 91 percent lanthanum oxide when oxygen was used for oxidation. Lanthanum recovery, however, was only 77 percent. Slightly less favorable results were obtained with air. Neither gas produced a sharp pH stabilization, such as occurred when ozone was the oxidant. This factor was a considerable disadvantage, because the stabilizing of the solution $\mathrm{pH}$ was a reliable indication of complete $\mathrm{CeO}_{2}$ precipitation. A further disadvantage in the use of air or oxygen streams is that extended operation at high temperature and high $\mathrm{pH}$ resulted in the complete precipitation of all the rare-earth elements in the charge solution. 


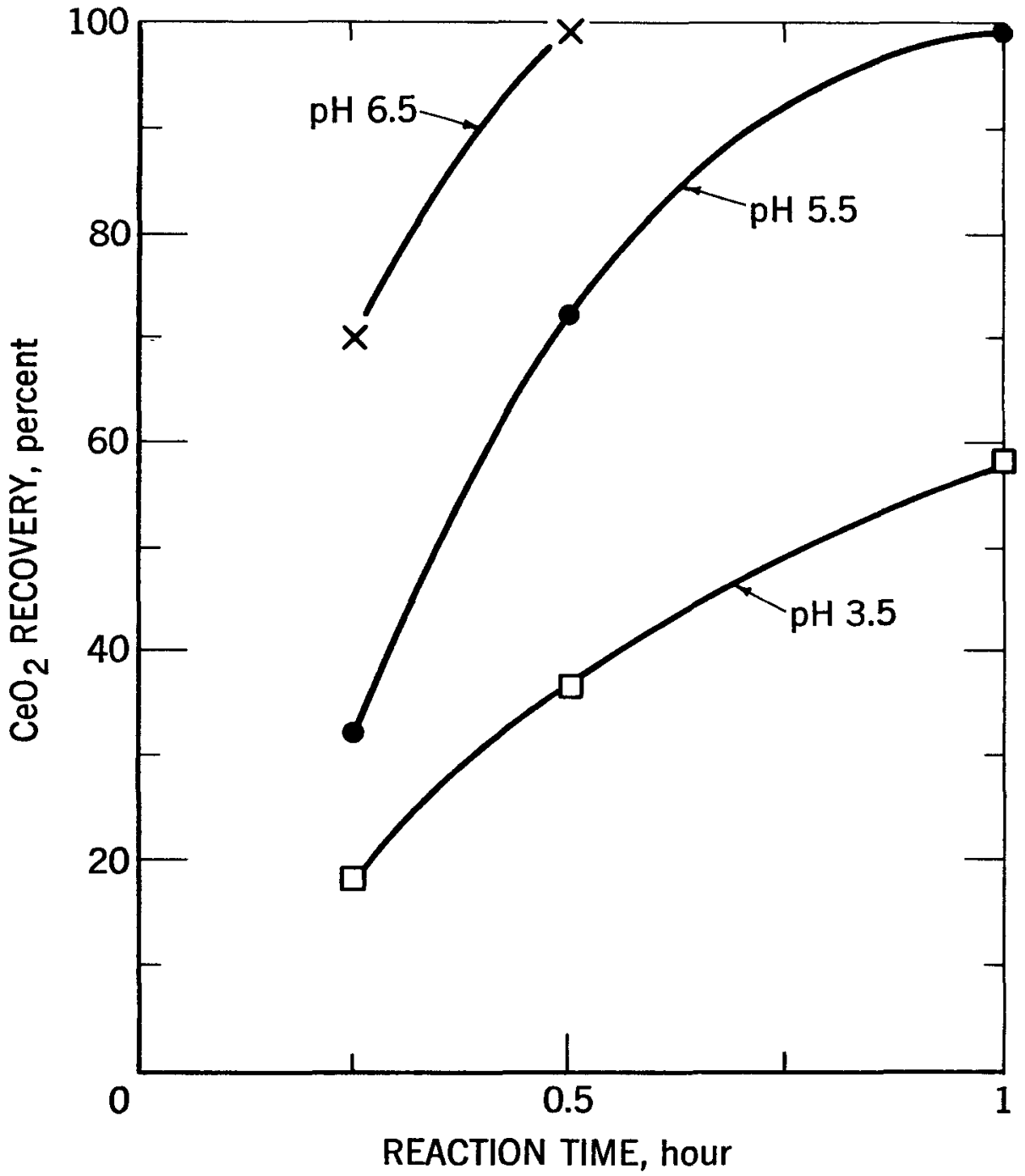

FIGURE 2. - Effect of Reaction Time on $\mathrm{CeO}_{2}$ Recovery From Lanthanide Chloride Solution at $85^{\circ} \mathrm{C}$.
Initial experiments with ozone were conducted to determine the variation of $\mathrm{CeO}_{2}$ pre. cipitation from chloride solutions with time at varied $\mathrm{pH}$ values and temperatures. Figure 1 shows that $\mathrm{CeO}_{2}$ precipitation increases with both increasing reaction time and increasing $\mathrm{pH}$ at ambient temperature. At 3-hours reaction time, $\mathrm{CeO}_{2}$ precipitation increased from 36 to 98 percent when the $\mathrm{pH}$ was increased from 3.5 to 4.5 . Greater than 99-percent precipitation of $\mathrm{CeO}_{2}$ occurred in 2 hours at $\mathrm{pH} \mathrm{5.5}$, whereas only 1 hour was required for 99-percent precipitation at $\mathrm{pH} 6.5$. Hydrogen ion concentrations above pH 6.5 were not investigated because of the formation of rare -

earth hydroxides. The same trend can be seen in figure 2 for precipitation at $85^{\circ} \mathrm{C}$; however, at the higher temperature the rate of $\mathrm{CeO}_{2}$ precipitation increased considerably. Complete precipitation of $\mathrm{CeO}_{2}$ occurred in 1 hour at $\mathrm{pH} 5.5$, and only one-half hour was required at $\mathrm{pH} 6.5$.

Subsequent experiments with ozone were conducted using rare-earth sulfate, nitrate, or chloride solutions to obtain recovery and purity data for cerium and lanthanum compounds. The three anion species were included in the study, because it was not known if the differences in their abilities to form complex ions with the rare-earth elements would affect the recovery and purity of the $\mathrm{CeO}_{2}$ precipitate. In table $2 \mathrm{CeO}_{2}$ recovery and purity data obtained with the sulfate, nitrate, and chloride solutions at ambient temperature are summarized. A maximum $\mathrm{CeO}_{2}$ purity of 98 percent was obtained with the chloride solution, while a maximum purity of 92 to 93 percent was obtained with 
the sulfate and nitrate solutions. $\mathrm{CeO}_{2}$ recovery values of approximately 99 percent were common for all three anion species with $\mathrm{pH}$ values above 4.5. However, with $\mathrm{pH}$ values below 4.5 , precipitation from the sulfate solution resulted in recovery values markedly superior to those obtained with chloride or nitrate solutions. Presumably, complete $\mathrm{CeO}_{2}$ precipitation would occur using any of the three anionic species in the $\mathrm{pH}$ ranges covered if the ozone oxidation-precipitation reactions were continued for a sufficiently long time.

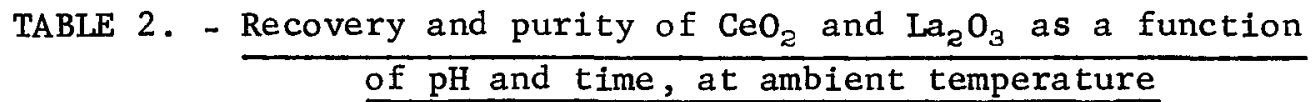

\begin{tabular}{|c|c|c|c|c|c|c|}
\hline \multirow[b]{2}{*}{ Anion } & \multirow[b]{2}{*}{$\mathrm{pH}$} & \multirow{2}{*}{$\begin{array}{l}\text { Reaction } \\
\text { time, } \\
\text { hours }\end{array}$} & \multicolumn{2}{|c|}{$\mathrm{CeO}_{2}$ in precipitate } & \multicolumn{2}{|c|}{$\mathrm{La}_{2} \mathrm{O}_{3}$ in filtrate } \\
\hline & & & $\begin{array}{c}\text { Recovery, } \\
\text { percent }\end{array}$ & $\begin{array}{l}\text { Purity, } \\
\text { percent }\end{array}$ & $\begin{array}{c}\text { Recovery, } \\
\text { percent }\end{array}$ & $\begin{array}{l}\text { Purity, } \\
\text { percent }\end{array}$ \\
\hline $\mathrm{so}_{4} \ldots \ldots \ldots \ldots$ & $\begin{array}{l}1.5 \\
2.5 \\
3.5 \\
4.5 \\
5.5\end{array}$ & $\begin{array}{l}3 \\
2 \\
2 \\
2 \\
2\end{array}$ & $\begin{array}{l}93 \\
97 \\
99.3 \\
99.8 \\
99.6\end{array}$ & $\begin{array}{l}79 \\
86 \\
85 \\
86 \\
92\end{array}$ & $\begin{array}{l}88 \\
92 \\
93 \\
93 \\
95\end{array}$ & $\begin{array}{l}63 \\
67 \\
69 \\
70 \\
75\end{array}$ \\
\hline $\mathrm{NO}_{3} \ldots \ldots \ldots \ldots$ & $\begin{array}{l}3.0 \\
4.5 \\
5.0 \\
5.5\end{array}$ & $\begin{array}{l}3 \\
3 \\
2 \\
1\end{array}$ & $\begin{array}{l}73 \\
99.2 \\
99.1 \\
98.8\end{array}$ & $\begin{array}{l}93 \\
93 \\
93 \\
89\end{array}$ & $\begin{array}{l}(1) \\
97 \\
98 \\
(1)\end{array}$ & $\begin{array}{l}\left({ }^{1}\right) \\
75 \\
73 \\
(1)\end{array}$ \\
\hline$c 1 \ldots \ldots \ldots \ldots$ & $\begin{array}{l}3.5 \\
4.5 \\
5.5 \\
6.5\end{array}$ & $\begin{array}{l}3 \\
3 \\
2 \\
1\end{array}$ & $\begin{array}{l}36 \\
98 \\
99.2 \\
99.8\end{array}$ & $\begin{array}{l}89 \\
98 \\
92 \\
76\end{array}$ & $\begin{array}{l}(1) \\
98 \\
94 \\
90\end{array}$ & $\begin{array}{l}(1) \\
70 \\
75 \\
88\end{array}$ \\
\hline
\end{tabular}

Not determined.

The effect of temperature on $\mathrm{CeO}_{2}$ recovery was determined at $85^{\circ} \mathrm{C}$ in the nitrate and chloride systems. Solubility limitations prevented investigation of rare-earth sulfate solutions at the higher temperature. Comparison of tables 2 and 3 shows that although the reaction time required to reach a given percentage of ceric oxide recovery at $85^{\circ} \mathrm{C}$ is substantially less than at ambient temperature, the cerium product is less pure. In one case a ceric oxide product of 95 percent purity was obtained in 1 hour with the chloride system, but recovery was only 58 percent. It is concluded that operation at ambient temperature is preferable for producing high-purity ceric oxide in high recovery.

Complete precipitation of pure cerium oxide would leave a trivalent rareearth mixture in solution containing a theoretical maximum of 72 -percent lanthanum oxide. However, the lanthanum recovery and analytical data obtained during the recovery of $\mathrm{CeO}_{2}$ (tables 1 and 2) show that at $\mathrm{pH}$ values of 4.5 and above the praseodymium, neodymium, and samarium started to precipitate selectively with the cerium, thereby leaving a more purified lanthanum product in the filtrate. The purity of the lanthanum in the filtrate increased with increasing $\mathrm{pH}$ up to the maximum value investigated, $\mathrm{pH} 6.5$. 
TABLE 3. - Recovery and purity of $\mathrm{CeO}_{2}$ and $\mathrm{La}_{2} \mathrm{O}_{3}$ as a function of $\mathrm{pH}$ and time, at $85^{\circ} \mathrm{C}$

\begin{tabular}{c|c|c|c|c|c|c}
\hline \multirow{2}{*}{ Anion } & $\mathrm{pH}$ & $\begin{array}{c}\text { Reaction } \\
\text { time, } \\
\text { hours }\end{array}$ & $\begin{array}{c}\mathrm{CeO}_{2} \text { in precipitate } \\
\begin{array}{c}\text { Recovery, } \\
\text { percent }\end{array}\end{array}$ & $\begin{array}{c}\text { Purity, } \\
\text { percent }\end{array}$ & $\begin{array}{c}\text { Recovery, } \\
\text { percent }\end{array}$ & $\begin{array}{c}\text { Purity, } \\
\text { percent }\end{array}$ \\
\hline $\mathrm{NO}_{3} \ldots \ldots \ldots \ldots \ldots \ldots$ & 5.5 & $\frac{1}{2}$ & 99.4 & 72 & 78 & 90 \\
& 6.5 & $\frac{1}{2}$ & 99.9 & 70 & 80 & 96 \\
& & 1 & 58 & 95 & 94 & 51 \\
& 3.5 & 1 & 99.9 & 90 & 97 & 75 \\
& 4.5 & 1 & 99.3 & 80 & 90 & 82 \\
\hline
\end{tabular}

The increase in purity occurred at ambient temperature as we11 as at $85^{\circ} \mathrm{C}$, although the highest lanthanum purity values were obtained at the higher temperature. At $85^{\circ} \mathrm{C}$ and $\mathrm{pH} 6.5,80$-percent recovery of 96 -percentpure lanthanum (oxide basis) was obtained with the nitrate system, and 88percent recovery of 94-percent-pure lanthanum with the chloride system. At ambient temperature, the best results were 88 -percent recovery of 90 -percentpure lanthanum. The best results seem to be obtained with operation at elevated temperature, especially since the reaction time was decreased from 1 hour to one-half hour by heating the solution to $85^{\circ} \mathrm{C}$. The lanthanum results obtained in the ozone system were notably superior to those obtained in the oxygen system mentioned previously.

Isolation and purification of both cerium and lanthanum in the bastnas ite mixture would require a two-step operation. In the first step, the primary precipitation of cerium and heavier rare-earth salts at $85^{\circ} \mathrm{C}$ would provide a purified lanthanum product in the filtrate. In the second step, the filtered precipitate would be redissolved in mineral acid at ambient temperature and reozonated to provide a pure $\mathrm{CeO}_{2}$ precipitate. Data given in table 4 are typical of the results obtained with such a two-step process.

TABLE 4. - Two-step recovery of $\mathrm{CeO}_{2}$ and $\mathrm{La}_{2} \mathrm{O}_{3}$

\begin{tabular}{|c|c|c|c|c|c|c|}
\hline Treatment & Anion & Temperature & $\mathrm{pH}$ & $\begin{array}{l}\text { Reaction } \\
\text { time, hours }\end{array}$ & $\begin{array}{c}\text { Recovery, } \\
\text { percent }\end{array}$ & $\begin{array}{l}\text { Purity, } \\
\text { percent }\end{array}$ \\
\hline $\begin{array}{l}\text { Step } 1 \text {, lanthanum } \\
\text { recovery. }\end{array}$ & $\left\{\begin{array}{l}\mathrm{NO}_{3} \\
\mathrm{Cl}\end{array}\right.$ & $\begin{array}{ll}85^{\circ} \mathrm{C} \\
85^{\circ} \mathrm{C}\end{array}$ & $\begin{array}{l}6.5 \\
6.5\end{array}$ & $\begin{array}{l}\frac{1}{2} \\
\frac{1}{2}\end{array}$ & $\begin{array}{l}89 \\
83\end{array}$ & $\begin{array}{l}95 \\
95\end{array}$ \\
\hline $\begin{array}{l}\text { Step } 2 \text {, cerium } \\
\text { recovery. }\end{array}$ & $\left\{\begin{array}{l}\mathrm{NO}_{3} \\
\mathrm{Cl}\end{array}\right.$ & $\begin{array}{l}\text { Ambient } \\
\text { Ambient }\end{array}$ & $\begin{array}{l}4.5 \\
4.5\end{array}$ & $\begin{array}{l}3 \\
3\end{array}$ & $\begin{array}{l}94 \\
97\end{array}$ & $\begin{array}{l}98 \\
96\end{array}$ \\
\hline
\end{tabular}

The rare-earth fraction in the first filtrate from the ozone oxidationprecipitation reaction at $85^{\circ} \mathrm{C}$ and $\mathrm{pH} 6.5$ analyzed 95 percent lanthanum oxide for both the chloride and nitrate systems. Corresponding lanthanum recoveries were 89 percent for the nitrate system and 83 percent for the chloride system. Subsequent recovery of cerium from the heavier lanthanides by a second ozonation step at ambient temperature and $\mathrm{pH} 4.5$ produced a slightly purer $\mathrm{CeO}_{2}$ 
product from the nitrate system than from the chloride system (98 percent versus 96 percent), but the $\mathrm{CeO}_{2}$ recovery from the chloride system was higher (97 percent versus 94 percent). In general, the anion is of minor importance, and it should be noted that it can be changed when redissolving the precipitate from the first step. This change of anionic specie could be of importance for subsequent separation of the rare-earth elements heavier than cerium.

Production of high-purity ceric oxide was shown to be feasible by dis solving the 98-percent ceric oxide ozonation product in hydrochloric acid and repeating the ozone oxidation-precipitation step at ambient temperature and $\mathrm{pH}$ 4.5. The purity of the resulting ceric oxide precipitate was in excess of 99.9 percent, and recovery was essentially complete.

The effect of rare-earth concentration on cerium recovery and purity was investigated by ozonating a $200 \mathrm{-g} / 1$ solution of bastnasite-type chloride salts at ambient temperature and $\mathrm{pH} 4.5$. Typical $\mathrm{CeO}_{2}$ recovery values were in the 97 percent range, and the corresponding $\mathrm{CeO}_{2}$ purity decreased from the 98 percent obtained at a concentration of $12 \mathrm{~g} / 1$ to 93 percent. The reduced product purity was partially mitigated, however, by an increase in the precipitation rate to 1.8 times that obtained at the lower concentration.

The stoichiometry of the reaction occurring between ozone and cerium in solution was investigated by oxidizing high-purity cerous nitrate, chloride, or sulfate solutions at ambient temperature. No ammonia was added during the tests, and the $\mathrm{pH}$ dropped from an initial value of 6 to 2.5 for the chloride solutions. No precipitation occurred in the nitrate solution, possibly because of the stability of the anionic ceric nitrate complex at low pH. For the chloride and sulfate solutions, the ratios between the $\mathrm{CeO}_{2}$ recovered, the ozone consumed, and the hydrogen ions produced at ambient temperature correspond to the following equation given for the chloride system.

$$
2 \mathrm{CeCl}_{3}+\mathrm{O}_{3}+3 \mathrm{H}_{2} \mathrm{O} \rightarrow 2 \mathrm{CeO}_{2}+6 \mathrm{HCl}+\mathrm{O}_{2} \text {. }
$$

The experimental data checked within 5 percent for equation 1 . It is of interest in equation 1 that the ozone furnishes only 25 percent of the oxygen necessary to form the ceric oxide.

\section{CONCLUSIONS}

Cerium can be effectively recovered from complex rare-earth mixtures in solution by a simple, ambient temperature, oxidation-precipitation process utilizing ozone to precipitate $\mathrm{CeO}_{2}$. Operation in the $\mathrm{pH}$ range from 4.0 to 5.0 is recommended. The ozonation technique is also applicable to lanthanum purification by operating at $85^{\circ} \mathrm{C}$, preferably at $\mathrm{pH}$ values greater than 5.0. The techniques involved are simple, relatively rapid, and produce commercialgrade cerium and lanthanum compounds in high yields. In addition, separation and purification are accomplished without introducing contaminants into the system. 
REFERENCES 5

1. American Chemical Society. Ozone Chemistry and Technology. 1959, 465 pp.

2. Dyrssen, David. Phenylbenzohydroxamic Acid. Acta Chem. Scand., v. 10, No. 3, 1956, pp. 353-359.

3. Moeller, Therald, and Howard E. Kremers. The Basicity Characteristics of Scandium, Yttrium, and the Rare Earth Elements. Chem. Rev., v. 37, No. 1, August 1945, pp. 97-159.

4. Patkin, P. N. (Separation of Cerium From Natura1 Mixtures and Extraction of Its Compounds in a High Degree of Purity.) Dokl. Mosk. Sel'skokhoz. Akad., Nauchn. Konf. 1, No. 30, 1957, pp. 222-227.

5. Powe11, J. E., and F. H. Spedding. Basic Principles Involved in the Macro-Separation of Adjacent Rare Earths From Each Other by Means of Ion Exchange. Iowa State College (Ames, Iowa), ISC-857, $1956,47 \mathrm{Pp}$.

6. Vickery, R. C. Chemistry of the Lanthanons. Academic Press, Inc., New York, 1953, 296 pp.

7. Warf, James C. Extraction of Cerium (IV) Nitrate by Butyl Phosphate. J. Am. Chem. Soc., v. 71, No. 9, September 1949, pp. 3257-3258.

${ }^{5}$ Titles enclosed in parentheses are translations from the language in which the item was originally published. 